\title{
Author Correction: Recovering a Black Cemetery: Automated Mapping of Hidden Gravesites Using an sUAV and GIS in East End Cemetery, Richmond, VA
}

\author{
Stephanie A. Spera ${ }^{1}$. Matthew S. Franklin ${ }^{1}$ - Elizabeth A. Zizzamia ${ }^{1}$. \\ Ryan K. Smith ${ }^{2}$
}

(c) The Author(s) 2022

\section{Author Correction: International Journal of Historical Archaeology https://doi.org/10.1007/s10761-021-00642-3}

Duplicate sentences are found in the 2nd and 3rd paragraphs of the Concluding Remarks section.

The original article has been corrected.

\begin{abstract}
Open Access This article is licensed under a Creative Commons Attribution 4.0 International License, which permits use, sharing, adaptation, distribution and reproduction in any medium or format, as long as you give appropriate credit to the original author(s) and the source, provide a link to the Creative Commons licence, and indicate if changes were made. The images or other third party material in this article are included in the article's Creative Commons licence, unless indicated otherwise in a credit line to the material. If material is not included in the article's Creative Commons licence and your intended use is not permitted by statutory regulation or exceeds the permitted use, you will need to obtain permission directly from the copyright holder. To view a copy of this licence, visit http://creativecommons.org/ licenses/by/4.0/.
\end{abstract}

Publisher's Note Springer Nature remains neutral with regard to jurisdictional claims in published maps and institutional affiliations.

The original article can be found online at https://doi.org/10.1007/s10761-021-00642-3.

Stephanie A. Spera

sspera@richmond.edu

1 Department of Geography and the Environment, Carole Weinstein International Center, University of Richmond, 211 Richmond Way, Richmond, VA 23173, USA

2 Department of History, Virginia Commonwealth University, Richmond, VA 23284, USA 